\title{
FACTORS AFFECTING URBANIZATION IN THE RURAL AREAS
}

\begin{abstract}
Virginija GURSKIENE், Institute of Land Management and Geomatics, Faculty of Water and Land Management, Vytautas Magnus University, K. Donelaicio str. 58, 44248 Kaunas, Lithuania, virginija.gurskiene@ vdu.lt

Justė URBAITIENÉ, Institute of Land Management and Geomatics, Faculty of Water and Land Management, Vytautas Magnus University, address: K. Donelaicio str. 58, 44248 Kaunas, Lithuania, justeurbaitiene@ gmail.com

Vida MALIENÉ, nstitute of Land Management and Geomatics, Faculty of Water and Land Management, Vytautas Magnus University, address: K. Donelaicio str. 58, 44248 Kaunas, vida.maliene@ vdu.lt

Velta PARSOVA, Department of Land Management and Geodesy of Faculty of Environmental and Civil Engineering, Latvia University of Life Sciences and Technologies, address: 2 Liela Street, Jelgava, LV-3001, Latvia, velta@ parsova.lv
\end{abstract}

By overviewing the developmental trends of Lithuanian cities, rapid growth in the urbanization of smaller suburb areas is observed. The aim of the research is to determine the factors impacting the urbanization of rural areas. The built-up areas of Kaunas district municipality and factors impacting their distribution are the object of this research. The largest built-up areas are in the subdistricts where cities are deployed as well as in subdistricts having the best living and recreational circumstances. When conducting the research, factors impacting the distribution of the built-up areas have been analysed.

In Kaunas district municipality, beneficial circumstances for the urbanization development exist since the population growth in the last 7 years corresponds to the optimistic scenarios projected in the general plan. It has been determined that 3 factors have the greatest impact on the built-up areas: the area of the subdistrict itself, the distance to the centre of the region and the market value of the land.

Keywords: built-up areas, urbanization development

\section{INTRODUCTION}

The most active processes of urbanization take place next to the big cities (Aleknavičius, 2010; Buxton et al., 2006; Kasnauskienè et al., 2009). In the suburb areas, the built-up areas are rapidly growing. Gradually, the processes of urbanization also start impacting smaller residential areas (Aleknavičius, 2012; Dringelis, 2013). The urbanized landscape and the landscape that is being urbanized are highly dynamic, intricate, and multifunctional (Antrop, 2004; Dokurnevič et al., 2010; Gražulevičiūtė-Vileniškè, 2011; Laukaitytė-Malžinskienė, 2005). Thus, comprehensive observations of the landscape change are essential in order to reach crucial decisions on time.

The potential of district development is essentially determined by the number of residents and its social and demographic structure; the size of the workforce and the professional (educational attainment) structure; the preparation of the community and business structures to act in an active manner; the financial resources, including prices of land (Kaunas district municipality..., 2014).

Kaunas district municipality, situated next to Kaunas, the second biggest city in Lithuania, is rapidly growing, the population is increasing while the anthropogenic load of rural territories is also rising simultaneously. Therefore, the analysis of the peculiarities of Kaunas district urbanization in each subdistrict individually is relevant.

The aim of the research is to determine the factors impacting the urbanization of rural areas. While conducting this research, the built-up areas have been selected as the main indicator of urbanization. Factors impacting the distribution and changes of these areas have been analysed. The research has been conducted by examining the data of Kaunas district municipality.

\section{RESEARCH METHODOLOGY}

When conducting the research, the inductive and deductive methods, mathematical-statistical data analysis (Čekanavičius et al., 2014) and interviews with the staff of urbanistic branches of the Kaunas city and the Kaunas district municipalities administrations have been employed.

In order to conduct the research, the statistical and cartographic data published by the Lithuanian Department of Statistics, National Land Service under the Ministry of Agriculture of the Republic of Lithuania (Lietuvos Respublikos..., 2012; 2013; 2014; 2015; 2016; 2017; 2018) and other institutions (Regionų geoinformacinès..., 2019; Valstybine teritoriju..., 2019) has been used. Part of the data has been obtained from the spatial data sets of the Land Information System (Žemès informacinè..., 2019). The collected information has been divided on the grounds of the subdistricts. 22

Copyright (C) 2019 The Authors. Published by Vytautas Magnus University. This is an open-access article distributed under the terms of the Creative Commons Attribution License (CC BY 4.0), which permits unrestricted use, distribution, and reproduction in any medium, provided the original author and source are credited. 
subdistricts and their groups have been examined. When collecting the data, some of the subdistricts have merged. The average area of the analysed unit is approximately 7,180 ha. Based on the information from the spatial data sets of the Land Information System, the agricultural areas in the cadastre, distances from the centres of subdistricts to the centre of the region and to the national roads as well as other indicators have been calculated.

According to the data of population census from the Lithuanian Department of Statistics (Gyventojai, 2019), the population change in subdistricts has been analysed. By applying the primary data from the State Enterprise Centre of Registers for the mass valuation (Masinio vertinimo..., 2019), the average market value of agricultural lands in individual subdistricts of Kaunas district municipality has been calculated. The obtained values have been compared with the published market prices of agricultural lands (on aruodas.lt website).

In order to assess the subdistrict urbanization of Kaunas district municipality, the multi-criteria analysis has been carried out. The Visual Promethee software was selected for the research. Visual PROMETHEE is a multicriteria decision aid software. It is designed to help to: evaluate several possible decisions, identify the best possible decision, rank possible decisions from the best to the worst one, visualize decision or evaluation problems, ect. (Visual Promethee, 2014; Promethee methods, 2019). The main objective sought after by employing this program has been to examine and determine which subdistricts are the most appealing from the point of urbanization. The significance of the criterion was analysed according to the obtained data, distinguishing the territories of cadastral areas. The resulting data was fed into the above-mentioned program, which calculates the criteria and chooses the best alternative for the task. By performing a multi-criteria analysis with the Promethee software, the following study has sought to identify the subdistrict of Kaunas district with the best conditions for choosing a new residence. The significance of the criterion has been determined by the study of other authors and the recommendations of experts - there are employees of Kaunas city and Kaunas district municipalities administrations.

Twenty-two alternatives were selected for this study - these are the subdistricts in Kaunas district and 9 criteria have been defined as well (Table 1).

Table 1. Criteria used in the analysis and their justification

\begin{tabular}{|l|l|}
\hline \multicolumn{1}{|c|}{ Criteria } & \multicolumn{1}{c|}{ Identification and justification of criteria } \\
\hline $\begin{array}{l}\text { 1. Total area of the } \\
\text { subdistrict in ha }\end{array}$ & $\begin{array}{l}\text { This is a very important indicator in determining both population density and market value. The land is a } \\
\text { finite resource and the way in which it is used depends on changes in the environment that have a major } \\
\text { impact on quality of life, the economy and infrastructure. }\end{array}$ \\
\hline 2. Built-up area in ha & $\begin{array}{l}\text { Land occupied by structures other than roads: squares, stadiums, airfields, courtyards, gazons, cemeteries, } \\
\text { parcels or portions of land owned by households (www.zis.lt) }\end{array}$ \\
\hline $\begin{array}{l}\text { 3. Green area and } \\
\text { water bodies in ha }\end{array}$ & $\begin{array}{l}\text { The natural environment is important. These include meadows and pastures, unused land, forests, tree and } \\
\text { shrub plantations, gardens. Waters: Lakes, Rivers, Ponds (www.zis.lt) }\end{array}$ \\
\hline 4. Population density & Population collected from 2011 census data. Population density in subdistricts was calculated. \\
\hline $\begin{array}{l}\text { 5. Average market } \\
\text { value of immovable } \\
\text { property (agricultural } \\
\text { land) in euro per ha }\end{array}$ & $\begin{array}{l}\text { This value is established for agricultural land. It is derived from the value zones and formulas provided by } \\
\text { the Center of Registers. The values obtained are compared with the prices of the plots for sale, which are } \\
\text { given in the advertisements (www.aruodas.lt). }\end{array}$ \\
\hline $\begin{array}{l}\text { 6. Distance to Kaunas } \\
\text { city, km }\end{array}$ & The distance to the city center was measured using the maps.lt website. \\
\hline 7. Medical institution & Information on the number of medical institutions collected (from www.ktlk.lt) \\
\hline $\begin{array}{l}\text { 8. Education } \\
\text { infrastructure }\end{array}$ & $\begin{array}{l}\text { The number of educational institutions was determined. The more such institutions, the more attractive } \\
\text { the place for young families to be. }\end{array}$ \\
\hline 9. Public transport & Public transport (from trafi.lt) is a prerequisite for communication for many people. \\
\hline
\end{tabular}

Five criteria have been minimised: total area of territory, built-up area, population density, average market value, and distance to Kaunas city. Three criteria have been maximised: green areas and water bodies, educational infrastructure and public transport. One of the criteria (medical institutions) has been assessed by the 'presence/absence' criterion.

This study has analysed the factors that influence the distribution of built-up areas in localities. The multivariate regression analysis has been performed. Links between the size of the built-up areas in subdistricts (y) and the selected factors $\left(\mathrm{x}_{1}-\mathrm{x}_{12}\right)$ have been examined. The following factors have been chosen: $\mathrm{x}_{1}-$ area of the subdistrict in ha, $\mathrm{x}_{2}-$ green area in ha, $\mathrm{x}_{3}-$ area of water bodies in ha, $\mathrm{x}_{4}$ - forest area in ha, $\mathrm{x}_{5}-$ arable land, $\mathrm{x}_{6}-$ population density, $\mathrm{x}_{7}-$ distance to Kaunas city, $\mathrm{x}_{8}-$ score of average soil productivity, $\mathrm{x}_{9}$ - average market value of immovable property (agricultural land) in euro per ha, $\mathrm{x}_{10}-$ number of land management projects of rural development.

The object of the research is the built-up areas of Kaunas district municipality and factors impacting their distribution.

\section{RESEARCH RESULTS}

The processes of urbanization cannot be analysed without considering the dynamics of population and its density since these processes are affected by them.

A beneficial demographic situation for the population growth has developed in Kaunas district municipality. This trend of population growth is also projected in the general plan of Kaunas district municipality area (2013). In order to 
assess the predictions foreseen in this plan, an overview of the population change during the first projected time period (2012-2019) and the last 3 years of the current period have been carried out (Table 2).

Table 2. Change in the number of habitual residents (composed based on Gyventojai... [Residents], 2019)

\begin{tabular}{|c|c|c|c|c|c|c|c|c|}
\hline Administrative unit & \multicolumn{2}{|c|}{ Residents (at the beginning of the year) } & \multicolumn{2}{c|}{ Change 2017-2018 } & \multicolumn{2}{c|}{ Change 2012-2019 } \\
\cline { 2 - 9 } & $\mathbf{2 0 1 2}$ & $\mathbf{2 0 1 7}$ & $\mathbf{2 0 1 8}$ & $\mathbf{2 0 1 9}$ & number & $\%$ & number & $\%$ \\
\hline Republic of Lithuania & 3003641 & 2847904 & 2808901 & 2793986 & -39003 & $-1,37$ & -209655 & $-7,50$ \\
\hline $\begin{array}{c}\text { Kaunas city } \\
\text { municipality }\end{array}$ & 310773 & 292691 & 288363 & 286763 & -4328 & $-1,48$ & -24010 & $-8,37$ \\
\hline $\begin{array}{c}\text { Kaunas district } \\
\text { municipality }\end{array}$ & 86109 & 91073 & 92644 & 95122 & +1571 & $+1,72$ & +9013 & $+9,48$ \\
\hline
\end{tabular}

It has been revealed that contrary to the majority of municipalities in Lithuania a trend of population growth is observed in Kaunas district municipality. By overviewing the change in only the number of habitual residents during the 2012-2019 period and by comparing it to the projections of the general plan, it is observed that the projected optimistic scenario of population growth (in which the projected population growth during this period was 9,590 residents) is achieved. The obtained difference from the projection is only 577 residents, i.e., only 6\%; such tendencies are observed in municipalities next to big cities alone.

The distribution of residents in the municipality is also relevant to the research. After examining the population census of the country in 2001 and 2011 (Gyventojai..., 2019) and calculating their distribution in the residential areas, it has been revealed that the most densely accommodated areas in Kaunas district municipality are city areas: Garliava, Vilkija, and Ežerèlis. In rural areas, the most densely accommodated area is Kačergine (495 residents per $1 \mathrm{~km}^{2}$ ). During the analysed 10 years, population decline was recorded only in 7 subdistricts (Babtai, Čekiškè, Ežerèlis, Garliava, Raudondvaris, Taurakiemis, Vandžiogala) out of 22; from 2001 till 2011, this decline reached 3,406 residents. Thus, a problem of population decline that is relevant in Lithuania, is not peculiar to Kaunas district municipality, since population growth is observed during this period.

The urbanization level is partly revealed by the built-up areas and the pace of their development. The development of suburban settlements impacted the growth of built-up areas. In the general plan (2014) of Kaunas district municipality area, the main attention is focused on the urbanization (zones of sports, tourism, and recreation) and the development of engineering networks in the rural areas. The municipality invests in the energetic modernisation of residential and public buildings, renovation of public parks and squares as well as landscape maintenance.

When analysing the change in the urbanized areas, it has been also determined to examine the change in the agricultural areas in Kaunas district municipality in recent years (Table 3).

Table 3. The change in agricultural areas in Kaunas district municipality, 1 January (composed based on Lietuvos Respublikos... [of the Republic of Lithuania], 2012; 2015; 2018)

\begin{tabular}{|c|c|c|c|c|c|}
\hline Land use & Units & $\mathbf{2 0 1 2}$ & $\mathbf{2 0 1 5}$ & $\mathbf{2 0 1 8}$ & Change 2012 - 2018 \\
\hline \multirow{2}{*}{ Agricultural land } & ha & $77,144.73$ & $76,486.64$ & $75,832.42$ & $-1,312.31$ \\
\cline { 2 - 6 } & $\%^{*}$ & 51.57 & 51.14 & 50.71 & -0.88 \\
\hline \multirow{2}{*}{ Forest } & ha & $48,958.30$ & $49,155.82$ & $48,463.07$ & -495.23 \\
\cline { 2 - 6 } & $\% *$ & 32.73 & 32.87 & 32.41 & -0.33 \\
\hline \multirow{2}{*}{ Roads } & ha & $2,867.30$ & $3,006.28$ & $3,078.91$ & 211.61 \\
\cline { 2 - 6 } & $\% *$ & 1.92 & 2.01 & 2.06 & +0.14 \\
\hline \multirow{2}{*}{ Built-up areas } & ha & $7,102.99$ & $9,291.10$ & $9,277.98$ & $2,174.99$ \\
\cline { 2 - 6 } & $\% *$ & 4.75 & 6.21 & 6.20 & +1.45 \\
\hline \multirow{2}{*}{ Water bodies } & ha & $7,399.05$ & $7,415.99$ & $7,456.50$ & 57.45 \\
\cline { 2 - 6 } & $\% *$ & 4.95 & 4.96 & 4.99 & +0.04 \\
\hline Other land & ha & 6123.10 & $4,193.52$ & $5,438.84$ & -684.26 \\
\hline Total in municipality & ha & $149,595.47$ & $149,549.35$ & $149,547.72$ & -47.75 \\
\hline
\end{tabular}

Note: $*$ - from the total area of the territory

When comparing the statistical data from 1 January 2012 and from 1 January 2018, it is observed that the built-up areas and areas of roads and water bodies are increasing. Due to this, the agricultural, forest and other areas are decreasing. In order to ensure a rational usage of the land and sustainable development of urbanized territories, to the extent possible, the general plan is especially significant.

The distribution of the built-up areas in individual locations is closely related to the population distribution. It has been revealed that the biggest built-up areas are in subdistricts with cities (Garliava subdistrict -82\%, Ežerėlis - 54\%, Vilkija - 51\%). This trend is influenced by the rapid growth in residential housing development. In addition, the impact of business development and ongoing social projects is observed. From the rural subdistricts, the built-up area constituting the utmost part of the total area (i.e. 40.4\%) is in Kačerginè subdistrict. Čekiškè subdistrict has the smallest built-up area. However, from old times Čekiške with its surroundings is viewed as the land of farmers.

The obtained indicators have been assessed by applying mathematical-statistical methods. After collecting information on the main indicators of Kaunas district municipality (Table 4), in order to identify the strength of their links, correlation analysis has been carried out. 
Table 4. Key indicators of Kaunas district municipality

\begin{tabular}{|c|c|c|c|c|}
\hline Years & Built-up areas $^{1}$, ha & Residents $^{2}$ & $\begin{array}{c}\text { Foreign investment }^{3}, \\
\text { million Eur }\end{array}$ & Agricultural land $^{1}$ ha \\
\hline $\mathbf{2 0 1 3}$ & $7,394.44$ & 86,419 & 478 & $77,021.73$ \\
\hline $\mathbf{2 0 1 4}$ & $9,291.11$ & 87,138 & 1206 & $76,541.23$ \\
\hline $\mathbf{2 0 1 5}$ & $9,296.76$ & 88,396 & 1279 & $76,486.64$ \\
\hline $\mathbf{2 0 1 6}$ & $9,274.9$ & 89,516 & 1486 & $76,059.54$ \\
\hline $\mathbf{2 0 1 7}$ & $9,274.9$ & 91,073 & 1519 & $75,824.13$ \\
\hline
\end{tabular}

Note: ${ }^{1}$ - Lietuvos Respublikos..., 2013; 2014; 2015;2016; 2017; ${ }^{2}$ - Gyventojai..., 2019; ${ }^{3}$ - Masinio..., 2019.

Strong links have been found between the built-up areas and the analysed factors (population, foreign investments, and agricultural areas). It has been determined that the development of urbanized areas depends on foreign investment. This link is not accidental since the value of the coefficient of determination $\mathrm{R}^{2}=0.894$ indicates that the correlation coefficient is $\mathrm{R}=0.94$. Hence, there is a significantly strong link between these factors. The dependence between agricultural areas and built-up areas develops in different directions, as with the decline in the agricultural areas, the builtup area increases.

The strongest links have been found between the size of foreign investments and the size of built-up areas. The development of urbanized areas is carried out at the expense of the agricultural areas.

The value and price of land play an important role in the urbanization of territories. According to the mass valuation of the immovable property conducted by the State Enterprise Centre of Registers and the methodology applied for this valuation, in individual subdistricts of Kaunas district municipality, average market values of agricultural land have been calculated. This type of land has been chosen as, in most cases, the urbanized areas are developed at the expense of the agricultural areas, after changing the land-use of the agricultural area.

Agricultural areas of the highest value have been determined in these rural subdistricts: Kačergine, Užliedžiai, and Domeikava. The beforementioned residential areas are close to Kaunas city and have great means of transportation to Kaunas and other places. The limited supply of immovable property in Kačergine and the relatively exceptional living conditions cause higher prices. Domeikava is the largest residential area having the status of a village in Lithuania. Užliedžiai was one of the first settlements in Kaunas district to pave the streets, develop the networks of electricity, plumbing, sewerage, and telephone lines before starting the constructions of residential buildings. The developed infrastructure attracts an increasing number of residents. Correspondingly, the market values of the land in the subdistricts that are the furthest from the Kaunas city centre, such as Čekiškè, Samylai, Taurakiemis, Vilkija and the surroundings of Vilkija, are significantly lower.

This study has analysed the factors that influence the distribution of built-up areas in localities. By applying the regression analysis, strong and reliable interlinks have been determined only with three factors. It has been identified that a strong link between the size of the built-up area (y) and the following factors exist: total area of the subdistrict $\left(\mathrm{x}_{1}\right)$, distance to the centre of the region - Kaunas city $\left(\mathrm{x}_{7}\right)$, and the average market value of immovable property (agricultural land) $\left(\mathrm{x}_{9}\right)$.

The final regression equation is as indicated:

where $\mathbf{y}$ is the built-up area in ha;

$$
y=802.24+0.026 * x_{1}-21.793 * x_{7}-0.00089 * x_{9}
$$

$\mathbf{x}_{\mathbf{1}}$ is the area of the subdistrict in ha;

$\mathbf{x}_{7}$ is the distance to Kaunas city centre in $\mathrm{km}$;

$\mathbf{x}_{\mathbf{9}}$ is the average market value of agricultural land in euro per ha.

By performing a multi-criteria analysis with the Promethee software, the following study has sought to identify the subdistrict of Kaunas district with the best conditions for choosing a new residence. The obtained data has been entered into a solution analysis software (Promethee), where the criteria are calculated according to the formulas and the best alternative for the task is chosen. Twenty-two alternatives (subdistricts or their groups in Kaunas district) have been selected for this study. Each alternative is characterised by 9 criteria. The data has been entered into a value table (matrix of effects) where the directions of the criteria have been indicated. The Promethee ranking test shows that the subdistrict with the worst situation for land selection at this time is Domeikava. By all criteria, Raudondvaris has the best conditions, with Samylai, Akademija and Ringaudai falling behind. The test is quite accurate as its results depend on the varying importance of the criteria. One of the models that can represent data is the Promethee Network (Figure). The top ranked subdistricts are at the top, while the rating of the subdistricts is decreasing with the decline. 


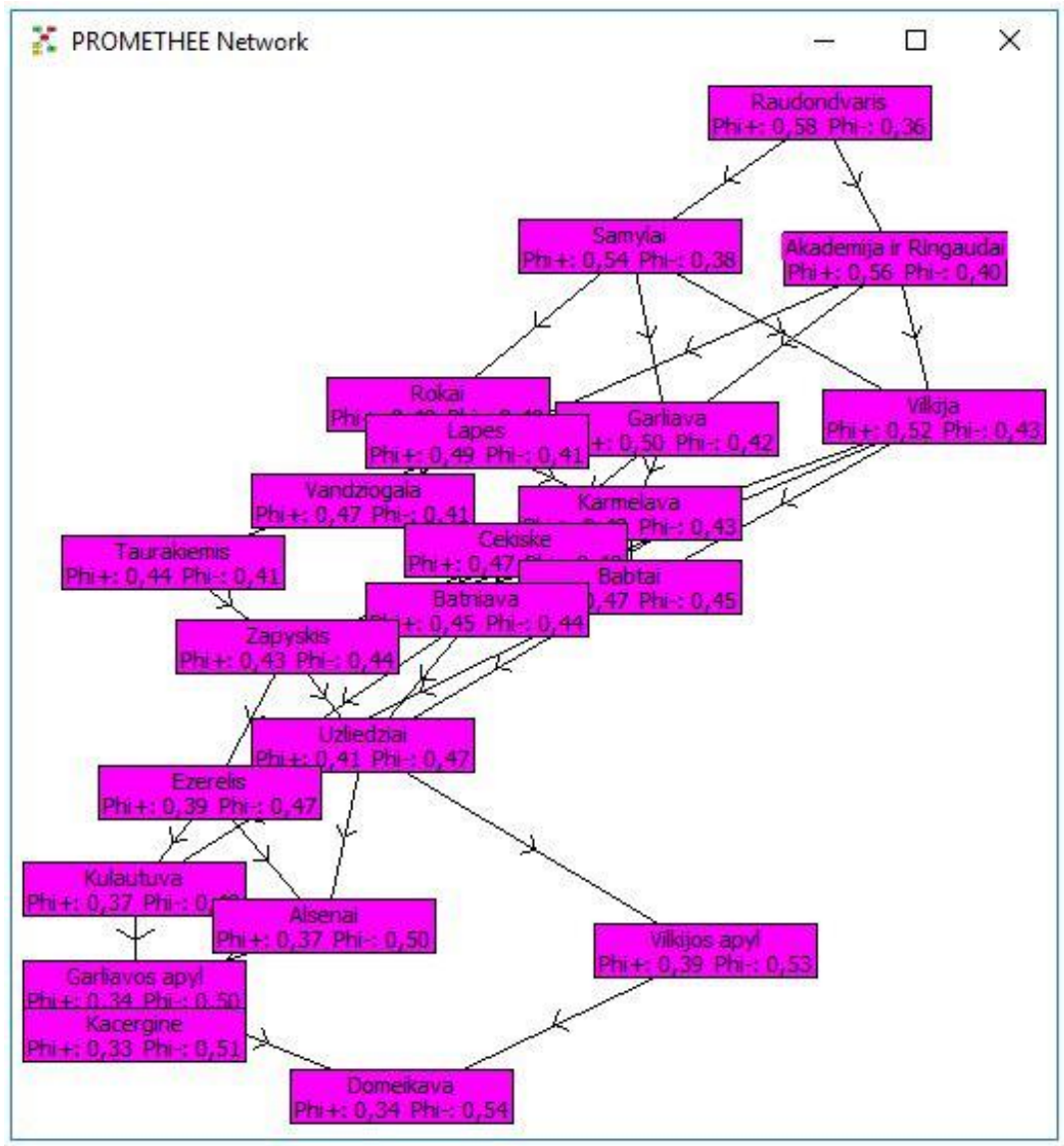

Figure 1. Evaluation of Kaunas subdistrict territories

A Comprehensive Ranking Test has been conducted next, showing which subdistricts have the greatest need for territorial development. According to the applied ranking test, the highest demand for urbanization has been found in subdistricts of Karmèlava, Akademija, Ringaudai, Raudondvaris, Domeikava, and Garliava, while the lowest demand has been determined in Čekiškè.

In summary, the size of built-up areas is influenced by three main factors: the area of the subdistrict, the distance to the centre of the region and the average market value of the land. In addition, one of the best options for choosing a plot of land for construction is in Raudondvaris subdistrict.

\section{CONCLUSIONS}

1. Kaunas district municipality has beneficial conditions for urbanization development due to the population growth in Kaunas district. During the analysed period of 2012-2019, the number of permanent residents increased by $9.48 \%$. These rates correspond to the optimistic scenario projected in the general plan of Kaunas district. It has been determined that the largest built-up areas are in subdistricts with cities (in Garliava subdistrict they constitute even $82 \%$ of the total area, in Ežerèlis - 54\%, and in Vilkija - 51\%); in the rural subdistricts, Kačerginè has the biggest built-up area (40.4\%). The smallest built-up area is in Čekiške subdistrict.

2. The most significant factor influencing the change of the urbanized territories and territories that are being urbanized is foreign investments, while population change is a less important factor. According to the obtained regression equations, it has been revealed that the size of the built-up areas is influenced by three co-acting factors: the area of the subdistrict, the distance to the centre of the region, and the market value of the land.

3. The most expensive agricultural land plots are located in Kačerginè, Domeikava, and Užliedžiai. The cheaper ones are situated farther from Kaunas city. According to the multi-criteria analysis, it has been identified that the best options for choosing a new land plot are in Raudondvaris subdistrict. It has been determined that the highest demand for territorial development is in the subdistricts of Karmèlava, Akademija, Ringaudai, Raudondvaris, Domeikava, and Garliava. The obtained results correspond to the solutions of the general plan. The lowest demand for urbanization is established in Čekiškè.

\section{REFERENCES}

1. Aleknavičius P. 2010. Urbanizuotų teritorijų plètra žemės ūkio paskirties žemëje. Urbanistinè drieka: miesto ir kaimo sandūra, pp. 55-62. (In Lithuanian).

2. Aleknavičius P. 2012. Lietuvos žemės naudojimo strateginės kryptys. Moksliniu tyrimu apibendrinimo: straipsniu rinkinys. Kaunas, p. 87. (In Lithuanian). 
3. Antrop M. 2004. Landscape change and the urbanization process in Europe. Landscape and Urban Planning, Vol. 67, pp. 9-26. https://doi.org/10.1016/S0169-2046(03)00026-4

4. Buxton M., Tieman G., Bekessy S., Budge T., Mercer D., Coote M., Morcombe J. 2006. Change and continuity in peri - urban Australia. State of the peri urban regions: a review of literature. Melbourne, RMIT University, 336.

5. Čekanavičius V., Murauskas G. 2014. Taikomoji regresinè analizė socialiniuose tyrimuose. Vilnius, 210. Available at: http://www.statistika.mif.vu.lt/wp-content/uploads/2014/04/regresine-analize.pdf (accessed on 02/03/2019). (In Lithuanian).

6. Dokurnevič E., Bagdzevičienè R. 2010. Mokslinių požiūrių sąveika regiono plètros modelyje. Lietuvos mokslas ir pramonė: tarptautinès mokslinès konferencijos pranešimu medžiaga, 227 p. (In Lithuanian).

7. Dringelis L. 2013. Lietuvos miestai, miesteliai ir kaimai: jų urbanistinių ir demografinių pokyčių įtaka šalies kraštovaizdžio erdvinès struktūros savitumui. Journal of Architecture and Urbanism, Vol. 37(4), pp. 310-323. https://doi.org/10.3846/20297955.2013.869884

8. Gyventojai: Oficialiosios statistikos portalas. 2019. Available at: https://osp.stat.gov.lt/gyventojai1 (accessed on 11/04/2019). (In Lithuanian).

9. Gražulevičiūtė-Vileniškė I., Ražauskaitė A., Ažukaitė L., Bartininkaitė V., Kulbokaitė L., Kameneckas J. 2011. Darnaus vystymosi principais paremtas kraštovaizdžių formavimas urbanizuotose teritorijose. Straipsnis, Kaunas. (In Lithuanian).

10. Kasnauskienė, G., Ambrozaitienė, D., Svidlerienė, D., Balandienė, R. 2009. Demografinè statistika Lietuvoje: pokyčiai atkūrus nepriklausomybę. Lietuvos statistikos darbai, pp. 31- 4 0. (In Lithuanian).

11. Kauno rajono bendrasis planas. 2014. Available at: https://www.krs.lt/savivaldybe/struktura-ir-kontaktai/administracijosdirektorius/urbanistikos-skyrius/bendrasis-ir-specialieji-planai/bendrasis-planas/ (accessed on 08/04/2019). (In Lithuanian).

12. Lietuvos Respublikos žemės fondas, 2012; 2013; 2014; 2015; 2016; 2017; 2018. Available at: http://nzt.lt/go.php/lit/Lietuvosrespublikos-zemes-fondas/1. (In Lithuanian).

13. Laukaitytė-Malžinskienė G. 2005. Priemiestinio kraštovaizdžio vertinimo ypatumai. Urbanistika ir architektūra, No. 29(2), pp. 81-89. (In Lithuanian).

14. Masinio vertinimo ataskaita, $2019 . \quad$ Available http://www.registrucentras.lt/ntr/vertinimas/masinis/masvert.php?src=1\&sav=63\&ver=29.

15. Promethee methods, 2019, Available at: http://www.promethee-gaia.net/methods.html (accessed on 15/04/2019). (In Lithuanian).

16. Regionų geoinformacinès aplinkos duomenys, 2019. Available at: https://regia.lt/map/kauno_r?lang=0 (accessed on 15/04/2019). (In Lithuanian).

17. Valstybinè teritorijų planavimo ir statybos inspekcija prie Aplinkos ministerijos, 2019. Available at: https://external.tpdr.lt/?formId=tpsearch (accessed on 02/03/2019). (In Lithuanian).

18. Visual PROMETHEE. Available at:http://www.promethee-gaia.net/assets/vpmanual.pdf (accessed on 05/24/2019)

19. Žemės infomacinė sistema, 2019. Internet access: https://www.geoportal.lt/map/index.jsp?mode=zis (accessed on 02/03/2019). (In Lithuanian). 